\title{
Family Matters: Modernise, Don't Abandon, Ius Sanguinis
}

\author{
Scott Titshaw
}

I appreciate the ideas that Costica Dumbrava and others have introduced into this debate. States' concerns about the quality and political consequences of their citizenship are important. But citizenship is a two-way street. Our discussion of ius sanguinis laws should extend beyond the concerns of states to also consider the serious practical consequences of citizenship laws on citizens, including the long-term unity and security of their families. Families facing instability or separation because children are denied their parents' citizenship are unlikely to be satisfied with the explanation that ius sanguinis is inadequate or historically tainted; the resulting individual sense of injustice might even discourage the loyalty and identification states seek in citizens.

This debate about citizenship transmission is necessary because of two modern changes in the facts of life: (1) increased international mobility based on cheap and easy transportation and communication; and (2) the advent and diffusion of assisted reproductive technology (ART) and new legal family forms (e.g., same-sex marriage and different-sex registered partnership). I will address each in turn. First, I'll explain why Dumbrava's proposal to abandon the ius sanguinis principle is an undesirable response to increased international mobility. Second, I'll build on Dumbrava's and Bauböck's recognition of the inadequacy of unlimited and exclusive ius sanguinis rules for today's families by suggesting that ius sanguinis be modernised rather than abandoned altogether. I'll also illustrate how citizenship in federal states can add an additional layer of complexity to any universal proposal regarding citizenship.

\section{In a mobile world children need their parents' citizenship}

Dumbrava's proposal to eliminate the ius sanguinis principle would increase, rather than decrease, problems based on greater international mobility. It would eliminate one tool parents currently use for transmitting 
citizenship to children conceived through ART. While current versions of ius sanguinis are inadequate to deal with other ART issues, that problem can be corrected. And, as Jannis Panagiotidis points out, abandoning ius sanguinis because of this inadequacy would be like 'throwing the baby out with the bathwater'. Most children are still conceived through sexual reproduction rather than ART, and many of their families would be worse off without ius sanguinis.

An example is easy to imagine. Let's say an Indian couple moves every seven years for employment reasons. They obtain residence permits, but not citizenship, in South Africa, the United Kingdom, and the United States, in turn. They also have a child in each country. Under ius soli regimes with no ius sanguinis rules, the children of these Indian parents would each have different passports (from South Africa, the UK, and the US). This might pose no problem in the short term. But what happens if a parent dies or loses his job?

Under a ius sanguinis regime, the surviving family members would be able to enter India and remain there together permanently as citizens. ${ }^{1}$

Dumbrava argues that such common citizenship is unnecessary to recognise and cement parent-child relationships if children of citizens have 'full migration rights. But 'migration rights' or benefits are substantially less stable than citizenship rights. What if a non-citizen family member becomes deportable because he or she commits a crime? ${ }^{2}$ What if both Indian parents die while the children are minors? Without ius sanguinis, the children with their different nationalities might not be allowed to remain together anywhere, let alone in India where their extended family members (grandparents, aunts and uncles) most likely live.

Dumbrava's proposal of a universal legal status for all children would ameliorate some of these problems, but only until each child reaches the age of majority. At that time they might be separated from their parents and siblings.

1 India would have automatically recognised these children as Indian citizens through 2004; it still recognises a greatly eased path to apply for citizenship in this context. http://www.loc.gov/law/help/citizenship-pathways/india.php

2 While hardship of citizen relatives is sometimes considered, US immigration law generally requires removal of non-citizens who commit any of a long list of criminal infractions. 8 USC §1227(a)(2). https://www.law.cornell.edu/ uscode/text/8/1227 


\section{ART requires fixing family and citizenship law}

I agree with Dumbrava's and Bauböck's rejection of exclusive, unconditional ius sanguinis rules as inadequate in dealing with the consequences of ART and modern family law.

I disagree, however, with the conclusion Dumbrava draws from his argument that 'joint citizenship adds little to the legal and normative character of the parent-child relationship'. In fact, the permanence and stability stemming from common citizenship among close family members can have profound consequences for the unity required to develop and maintain family relationships.

I also disagree with Dumbrava's argument that 'the main problem' is that ius sanguinis 'is parasitic on external factors concerning the legal determination of parentage'. In fact, some federal States already delink federal citizenship determination and state or provincial family law, ${ }^{3}$ creating greater problems than do citizenship laws that reflect legal parentage. In the United States, for example, legal parentage is generally a matter of state law. Yet, the US Constitution defines citizenship as an exclusively federal matter, ${ }^{4}$ and Congress has established and revised a complex, autonomous algorithm for determining when a citizen parent transmits US citizenship to a child born abroad. ${ }^{5}$ The problematic example Dumbrava points out regarding parents' inability to transmit US citizenship to children conceived through ART was created by a misguided autonomous federal policy, not parentage determinations under family law. ${ }^{6}$ It could, and should, be

$3 \mathrm{HCCH}$ (2014), A Study of Legal Parentage and the Issues Arising from International Surrogacy Arrangements, Prel. Doc. No 3C. Hague Conference on Private International Law,66-68 (listing Australia, Canada and the United States as examples). Available at http://www.hcch.net/upload/wop/ gap2015pd03c_en.pdf

4 The Fourteenth Amendment guarantees that '[a]ll persons born or naturalized in the United States and subject to the jurisdiction thereof are citizens of the United States and the state in which they reside'. Not only does this Amendment adopt a nearly absolute ius soli rule, but it clarifies that citizenship is a purely federal matter, with no meaningful state role beyond establishment of its own standards for recognising state residence.

58 USC $§ \S 1401-1409$. Available at http://www.uscis.gov/sites/default/files/ ilink/docView/SLB/HTML/SLB/0-0-0-1/0-0-0-29/0-0-0-9696.html

6 Under current US law, a genetic and legal father and/or one or more legal and 'biological' mothers (i.e., genetic and gestational mother(s)) transmit birthright citizenship to children conceived through ART, but non-biological parents do not. Titshaw, S. (2014), 'A Transatlantic Rainbow Comparison: "Federalism" and Family-Based Immigration for Rainbow Families in the U.S. and the 
corrected by federal reinterpretation of its rules to rely on family law parentage determinations. ${ }^{7}$

Rather than misplaced reliance on family law, the problems Dumbrava and Bauböck describe regarding the application of ius sanguinis following ART are consequences of outdated family law or of international conflictof-law issues where relevant jurisdictions define parentage differently.

To the extent that the problems stem from conflict-of-law issues, it is worth noting that the Hague Conference on Private International Law is currently exploring whether to draft a multilateral instrument on international parentage and surrogacy, which might resolve some issues. ${ }^{8}$

To the extent that the problems stem from outdated family law, the best solution is to fix the family law. Family law generally reflects a more individualized, in-depth understanding of parent-child relationships than do citizenship or migration laws. Based on long experience and empirical data, family law tends to favour the stability of permanent family relationships with commensurate duties and benefits in the best interests of children. By tending to ensure the same citizenship for children and their parent(s), ius sanguinis rules also generally promote stable solutions in the best interests of children in a way that less permanent migration rules do not.

I agree with Bauböck that multiplicity of citizenships for children is generally not a problem, and I support his call for a more generous understanding of parenthood for purposes of citizenship transmission. But I would not opt for a ius filiationis proposal if it requires an entirely independent determination of social parenthood for citizenship transmission purposes. Officials dealing with citizenship issues are not as well suited to determine these issues as those administering family law. Also, too much generosity in this area might instigate cross-border mischief in familial disputes by 'social parents'.

E.U.', in C. Casonato \& A. Schuster (eds.), Rights on the Move: Rainbow Families in Europe: Proceedings of the conference: Trento, 16-17 October 2014, Trento: 189-200 (194-9). Trento: Università degli Studi di Trento, Facoltà di Giurisprudenza, available at http://eprints.biblio.unitn.it/4448/

7 Titshaw, S. (2013), 'Revisiting the Meaning of Marriage: Immigration for Same-Sex Spouses in a Post-Windsor World', Vand. L. Rev. (66): 167-177 (174-75), available at http://www.vanderbiltlawreview.org/2013/10/ revisiting-the-meaning-of-marriage-immigration-for-same-sex-spouses-in-apost-windsor-world.

8 At: http:/www.hcch.net/upload/wop/gap2015pd03a_en.pdf 
Instead, I would suggest replacing all outmoded rules that fail to consider parental intent and the best interests of the child in the context of children conceived through ART, whether these are family laws determining parentage or autonomous federal citizenship laws reading ius sanguinis as a literal 'right of blood'.

Open Access This chapter is licensed under the terms of the Creative Commons Attribution 4.0 International License (http://creativecommons.org/licenses/by/4.0/), which permits use, sharing, adaptation, distribution and reproduction in any medium or format, as long as you give appropriate credit to the original author(s) and the source, provide a link to the Creative Commons license and indicate if changes were made.

The images or other third party material in this chapter are included in the chapter's Creative Commons license, unless indicated otherwise in a credit line to the material. If material is not included in the chapter's Creative Commons license and your intended use is not permitted by statutory regulation or exceeds the permitted use, you will need to obtain permission directly from the copyright holder.

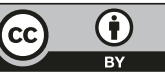

